\title{
Study of genetic diversity in Tunisian local cattle populations using ISSR markers
}

Haifa EL HENTATI ${ }^{*}$, Najia THAMRI ${ }^{2}$, Wissal DEROUICH ${ }^{1}$, Mouna HADHLI ${ }^{3}$, Taoufik BOUKHORSA ${ }^{4}$

${ }^{\prime}$ National Gene Bank of Tunisia, Boulevard of the leader Yasser Arafat, Charguia (1) 1080 Tunis, Ministry of Local Affairs and Environment, Tunisia

${ }^{2}$ Directorate of Genetic Improvement of Sidi Thabet, Office of Livestock and Pasture, 2020, Ariana, Tunisia

${ }^{3}$ Regional Directorate of the Office of Livestock and Pasture of Mateur, Av. Habib Bourguiba, 7030, Mateur, Bizerte, Tunisia

${ }^{4}$ Regional Direction of the Livestock and Pasture Office of Jendouba, Av. 9 Avril, B.P. 276, 8100, Jendouba, Tunisia

*Corresponding author: Dr Haifa El-Hentati, National Gene Bank of Tunisia, Boulevard of the leader Yasser Arafat, Charguia 1- 1080 Tunis, Tunisia E-mail: haifa_eh@yahoo.fr

Keywords: genetic diversity, ISSR, cattle, geographical areas

Publication date 31/12/2019, http://www.m.elewa.org/JAPS

1 ABSTRACT

The inter-simple DNA sequence repeat (ISSR) method was used to study genetic diversity in three local cattle from the north, northeast and north west of Tunisia. Twenty samples were analysed using three ISSR primers. In total, 22 bands were amplified of which 15 are polymorphic $(68.18 \%)$. The total genetic diversity $(\mathrm{Ht})$, genetic diversity within populations $(\mathrm{Hs})$, coefficient of gene differentiation (Gst) and gene flow $(\mathrm{Nm})$ were $0.2706,0.01314$, 0.8841 and 0.0656 . To better visualize the structure of the population, a UPGMA dendrogram constructed from the genetic distances of NEI shows that the populations of North (Bizerte) and Northeast (Nabeul) are genetically closest while that of Northwest (Jendouba and Siliana) is the furthest from the two others.

\section{INTRODUCTION}

Tunisian local cattle populations are characterized by its adaptability to harsh environment conditions and limited food resources. Despite its perfect harmony with difficult conditions, productivity remains low because of the often-unfavourable farming conditions (Altizer et al., 2013; Baccouche et al., 2015). To cope with increased food demands, Tunisia set up at the beginning of the seventy years, an absorption-crossing program of the local cattle through artificial insemination and natural mating (Djemali, 1992). This led to the decline in the importance of indigenous cattle and the collapse of their number. Introduction of productive exotic breeds raised the problems of rearing conditions mastery and animal adaptation. These constraints worsened due to climate change scenarios, especially global warming that can affect production, reproduction and even the existence of these exotic breeds (Schaal et al., 1991; Amamou et al., 2018). It is in this context, the present work is directed towards the study of the genetic diversity and phylogenetic relationships between three geographical populations of local cattle. 


\section{MATERIALS AND METHODS}

Twenty blood samples from Tunisian local cattle population namely Brown Atlas were collected from the jugular vein on EDTA tubes. Sampling was done in three geographic areas: the North (Bizerte; $n=8$ ), the Northeast (Nabeul; $\mathrm{n}=10$ ), the North West (Siliana and Jendouba; $n=2)$. The samples were stored at $20^{\circ} \mathrm{C}$ until DNA was extracted. Total genomic DNA was extracted using the Invitrogen iPrep machine and its kits, this system uses Magtration ${ }^{\circledR}$ Technology which is a magnetic bead-based method (Obata et al., 2001). After extraction, the quality and quantity of the DNA were evaluated by horizontal electrophoresis on an agarose gel $(0.8 \%)$. DNA standards of known concentration were used as a reference to determine the concentration of the DNA. All DNA samples were diluted to a concentration of $50 \mathrm{ng} / \mu \mathrm{l}$. DNA amplification of local cattle was performed using ISSR primers (UBC7, UBC 811, UBC 814). The PCR amplifications were carried out in a reaction volume of $25 \mu$ l containing $25 \mathrm{ng}$ of genomic DNA, $0.4 \mu \mathrm{M}$ of the ISSR primer $100 \mu \mathrm{M}$ of dNTP (Invitrogen), $2 \mathrm{mM}$ of $\mathrm{MgCl} 2,0.8$ units of Taq DNA polymerase (Invitrogen) and five $\mu$ of Taq buffer (5X). In order to detect any contamination, control reactions not containing the genomic DNA were carried out at each amplification. The ISSR-PCR reactions were conducted in a thermocycler (Kyratec) programmed to perform 45 cycles of $94^{\circ} \mathrm{C}$ for 40 seconds, TA (hybridization temperature of each primer) for 40 seconds and $72^{\circ} \mathrm{C}$ for 90 seconds; an initial denaturation step of 5 minutes at $94^{\circ} \mathrm{C}$ and a final eight minutes extension step at $72^{\circ} \mathrm{C}$ were included in the first and last cycles, respectively. The amplification products were separated by $3 \%$ agarose gel electrophoresis containing ethidium bromide in Tris Borate EDTA buffer and visualized under ultraviolet light. The Nei's gene diversity, the total genetic diversity $(\mathrm{Ht})$, genetic diversity within populations (Hs), coefficient of gene differentiation (Gst), gene flow $(\mathrm{Nm})$, unbiased Nei's distance (Nei, 1978) corrected for small samples and an unweighted pair-group method with arithmetic average (UPGMA) dendrogram were conducted using Popgene (Population Genetic Analysis) version 1.32 (Yeh et al., 1999) software. 


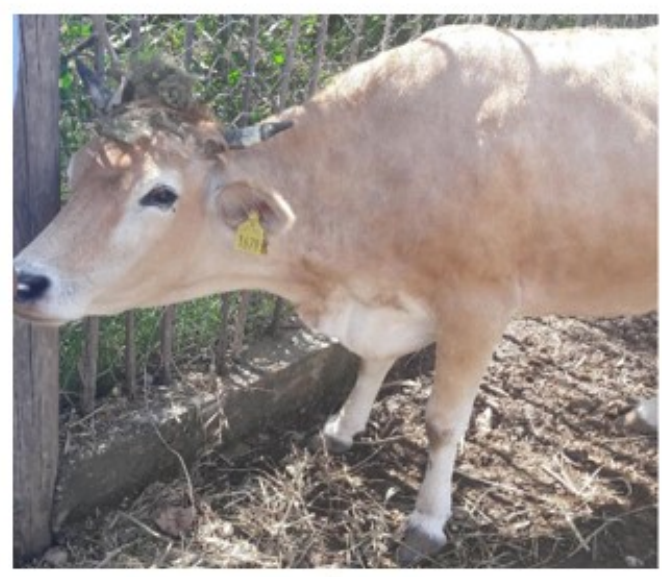

a

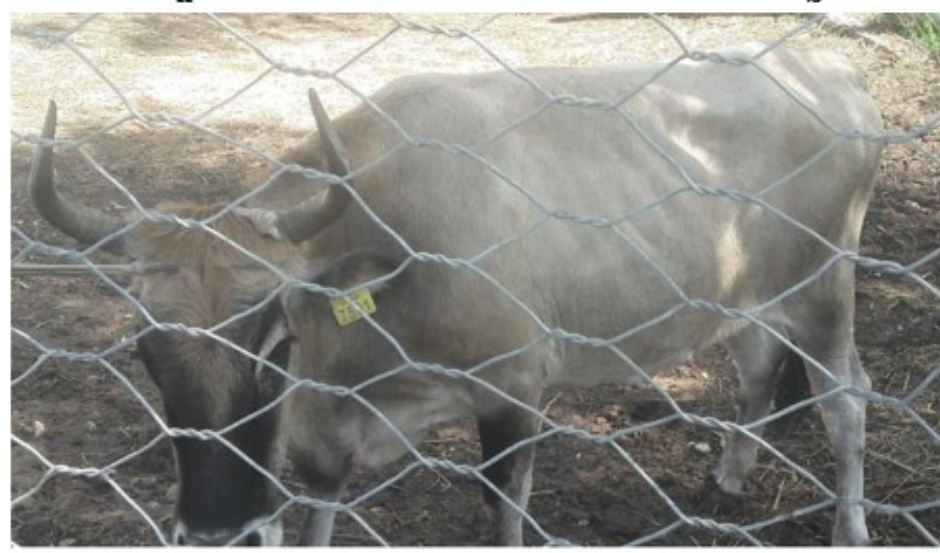

c

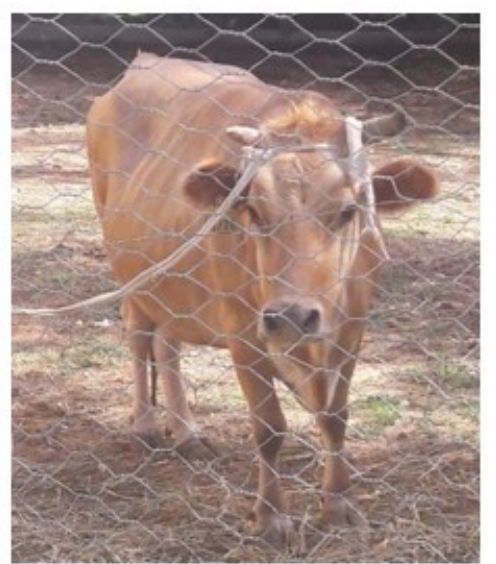

b

Figure 1: Tunisian local cattle: animals $\mathrm{a}, \mathrm{b}$ and $\mathrm{c}$ are respectively from northwest, north and northeast of Tunisia.

\section{$4 \quad$ RESULTS AND DISCISSION}

The amplification of the DNA of the different individuals using the three ISSR primers generated 22 bands (an average of 7.33 bands per primer), with a size ranging between $292 \mathrm{bp}$ and 2500 bp. Pashaei et al., 2009 detected band sizes ranging from 120 to $1600 \mathrm{bp}$ in Mazandarani cattle (Iran) using ISSR markers. Zietkiewicz et al. (1994) reported that ISSR markers are effective and simple to reveal genetic diversity in and between populations and can be used without prior knowledge of the sequence to be amplified. The ISSR technique consists of amplification of the DNA using a single primer composed of a microsatellite sequence; it is fast, inexpensive, has good reproducibility and can be easily used in population genetics studies ( $\mathrm{Li}$ and Xia 2005, Chen et al., 2005). In this work we obtained five specific bands, that is to say, present in a single individual; these are the size bands 292, 350, 773, 1600 and 2014 bp. Examples of amplification of the DNA of the local cattle by the ISSR primers are given in FIGS. 1, 2 and 3. Statistical analysis of the data generated the genetic diversity parameters summarized in Table 1. 


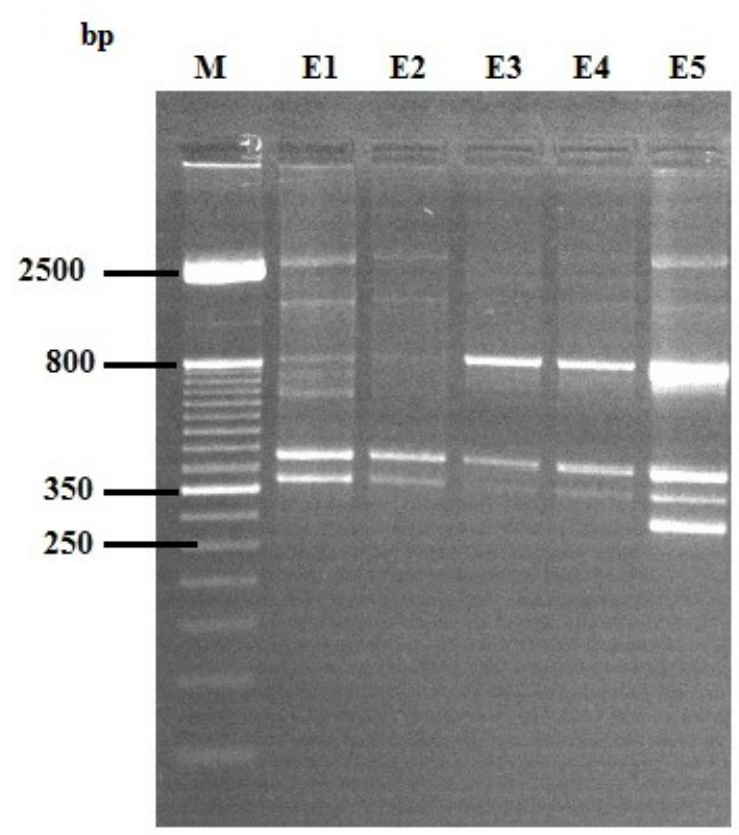

Figure 2: DNA amplification of local cattle by UBC 814 primer

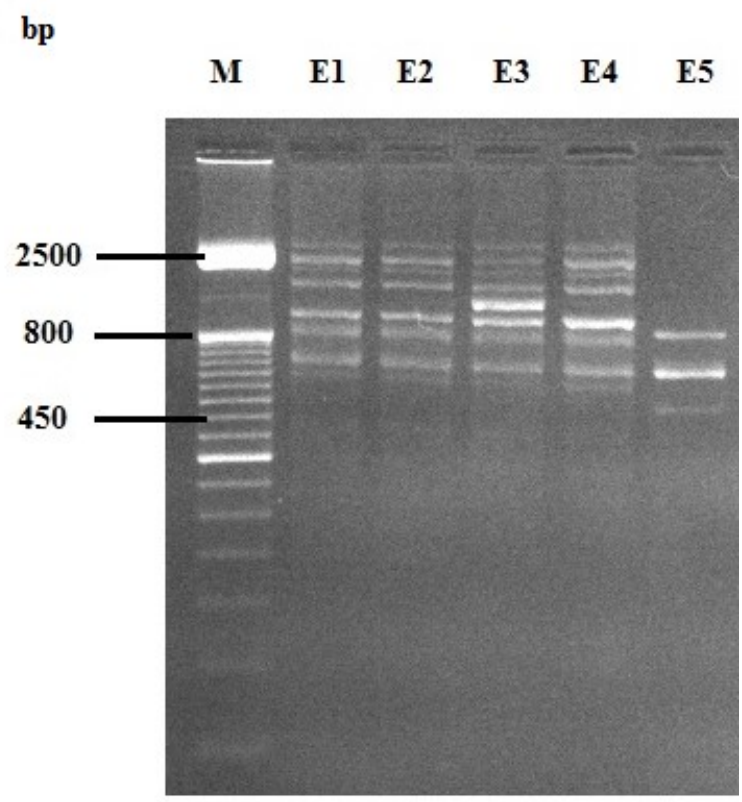

Figure 3: DNA amplification of local cattle by UBC07 primer 


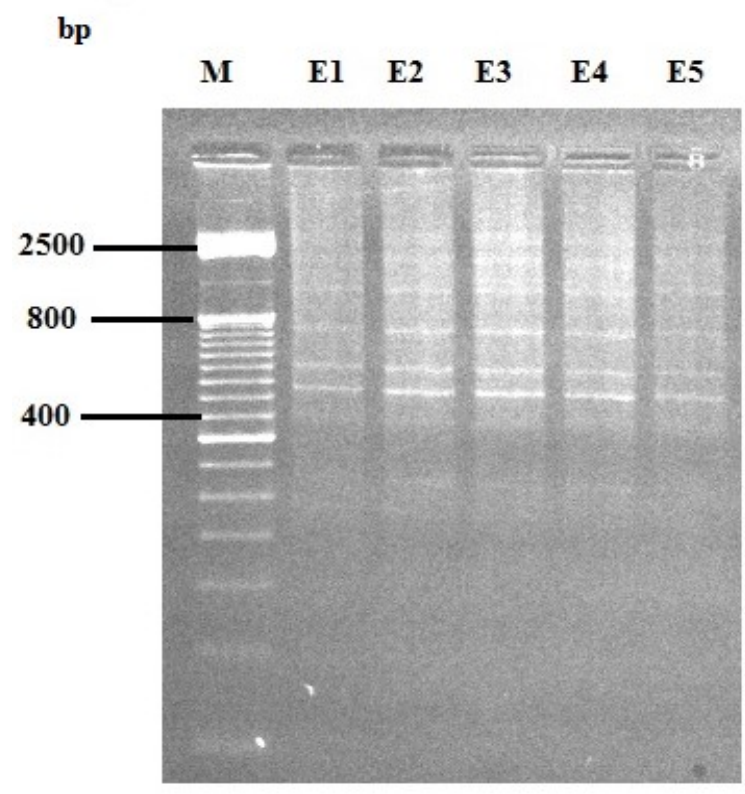

Figure 4: DNA amplification of local cattle by UBC811 primer

Table 1: Genetic diversity in the global population

\begin{tabular}{cccc}
\hline $\mathrm{h}^{(*)}$ & $\mathrm{I}^{(*)}$ & $\mathrm{NPL}^{(* * *)}$ & $\mathrm{P}^{(* * *)}$ \\
\hline 0.2194 & 0.3369 & 15 & $68.18 \%$ \\
\hline${ }^{(*)} \mathrm{h} \cdot$ Nei's $(1973)$ gene diversity & & &
\end{tabular}

${ }^{(*)}$ h: Nei's (1973) gene diversity

(**) I: Shannon's Information index (Lewontin, 1972)

${ }^{(* *)}$ NPL: The number of polymorphic loci

(***) The percentage of polymorphic loci

The $\mathrm{h}$ and $\mathrm{I}$ values found in this study are significantly higher than those detected by Pashaei et al., 2009 in a local cattle breed (Mazandaranian) in Iran $(0.14$ and 0.21 respectively). Similarly, the genetic diversity parameters found in this study among Tunisian local populations are much higher than those found by Askari et al. 2011. Indeed, these authors found values of genetic diversity and Shannon respectively of the order of 0.0950 0.1517 and $0.1576-0.2328$ in local Iranian populations of cattle. The Gst value found between the three studied populations is 0.8841 , this means that the variation between populations accounts for $88.81 \%$ of the total variability. This shows that there is a real geographical separation between populations. This is logical since the few found local animals live in mountainous areas. If these animals were raised in easily accessible areas, they would have been inseminated with the imported semen. As a result, the rate of effective migrants per generation (Nm) is low. According to Wright (1951), this value must be greater than 1 to allow homogenization of populations and avoid their divergence. A molecular study by Ben Jemaa et al. (2015) revealed a low level of divergence and high genetic diversity in Tunisian local cattle, reflecting low levels of genetic drift. Total genetic diversity $(\mathrm{Ht})$ and genetic diversity within populations ( $\mathrm{Hs}$ ) were 0.2706 and 0.0314 respectively (Table 2 ). A UPGMA dendrogram, grouping the three groups studied, was constructed from the genetic distances of Nei (Table 3); it shows two well-differentiated branches, the first includes the populations of North (Bizerte) and Northeast (Nabeul) while the second contains only the population of Northwest (Jendouba and Siliana) (Figure 4). 
Table 2: Nei's analysis of gene diversity in subdivided populations

\begin{tabular}{lllll}
\hline & $\mathrm{Ht}$ & $\mathrm{Hs}$ & Gst & $\mathrm{Nm} *$ \\
\hline Average & 0.2706 & 0.0314 & 0.8841 & 0.0656 \\
\hline Standard deviation & 0.0447 & 0.0035 & & \\
\hline
\end{tabular}

$* \mathrm{Nm}=$ estimate of gene flow from Gst, $\mathrm{Nm}=0.5(1-\mathrm{Gst}) / \mathrm{Gst}$ (McDermott $e$ al al., 1993)

Table 3: Nei's unbiased measures of genetic identity and genetic distance between the three geographical populations of the local cattle in Tunisia (Nei, 1978)

\begin{tabular}{llll} 
& North & Northeast & Northwest \\
\hline North & & 0.7712 & 0.4832 \\
\hline Northeast & 0.2598 & & 0.6424 \\
\hline Northwest & 0.7274 & 0.4425 & \\
\hline
\end{tabular}

Nei's genetic identity (above diagonal) and genetic distance (below diagonal)

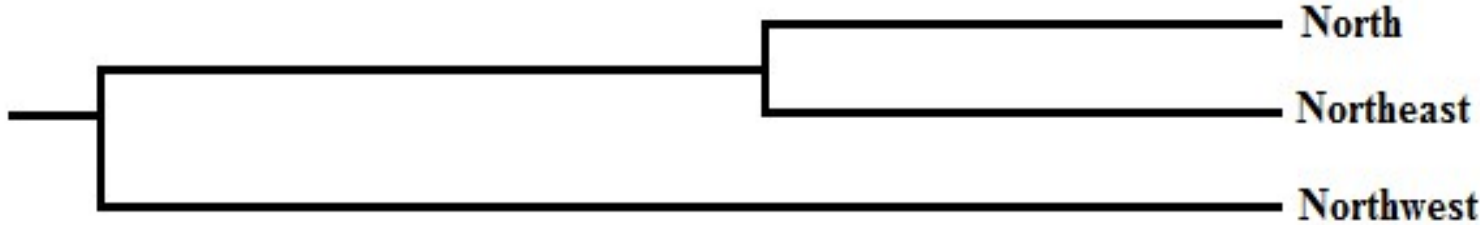

Figure 5: UPGMA dendrogram based Nei's (1978) Genetic distance

\section{CONCLUSION}

This work is part of a conservation program that involves the inventory, characterization and in vivo conservation of local cattle populations in Tunisia. Indeed, these cattle are currently in danger of extinction because of anarchic crossbreeding with the exogenous breeds considered productive. Surveys have

\section{REFERENCES}

Altizer S, Ostfeld RS, Johnson PTJ, Kutz S and Harvell CD: 2013. Climate change and infectious diseases: from evidence to a predictive framework. Science 80: 514519.

Amamou H, Ben Sassi M, Aouadi H, Khemiri $\mathrm{H}$, Mahouachi $\mathrm{M}$, Beckers $\mathrm{Y}$ and Hammami H: 2018. Climate changerelated risks and adaptation strategies as perceived in dairy cattle farming systems in Tunisia. Climate Risk Management. 20: $38-49$ confirmed the remarkable scarcity of these animals. Currently, we have focused on in vivo conservation of females and insemination of females by an animal seed previously produced from four bulls of the Brown Atlas breed. This study should be expanded by considering more polymorphic primers and molecular markers.

Askari N, Mohammadreza MA and Baghizadeh, A: 2011. ISSR markers for assessing DNA polymorphism and genetic characterization of cattle, goat and sheep populations. Iranian Journal of Biotechnology. 9(3): 222-229.

Baccouche R, Jemmali B, Haddad M, M'Hamdi $\mathrm{N}$ and Ben Hamouda: 2015. Phenotypic Characterization of Native Bovine Population in Northern Tunisia. Applied Science Reports. 10(1): 38-44.

Ben Jemaa S, Boussaha M, Ben Mehdi M, Lee JH and Lee S-H: 2015. Genome-wide 
insights into population structure and genetic history of Tunisian local cattle using the illumine bovinesnp50 beadchip. BMC Genomics 16:677.

Djemali M., 1992. National Report on Animal Genetic Resources. 39p

Lewontin RC: 1972. The apportionment of human diversity. Evol Bio. 6: 381-398.

Li F and Xia N: 2005. Population structure and genetic diversity of an endangered species, Glyptostrobus pensilis (Cupressaceae). Bot Bull Sinica. 46: 155162.

Nei M.: 1973. Analysis of gene diversity in subdivided populations. Proc. Nat. Acad. Sci. USA 70(12): 3321-3323.

Obata K, Segawa O, Yakabe M, Ishida Y, Kuroita T, Ikeda K, Kawakami B, Kawamura Y, Yohda M, Matsunaga T, Tajima H: 2001. Development of a novel method for operating magnetic particles, Magtration Technology, and its use for automating nucleic acid purification. J biosci Bioeng 91: 500-503.

Pashaei S, Azari MA, Hassani S, Khan Ahmadi A and Rostamzadeh J: 2009. Genetic
Diversity in Mazandaranian Native Cattle: A Comparison with Holstein Cattle, using ISSR Marker. Pakistan journal of biological sciences 12: 717 21.

Schaal BA, Leverich WJ, Rogstad SH: 1991. Comparison of methods for assessing genetic variation in plant conservation biology. Genetics and Conservation of Rare Plants. Oxford University Press, New York. PP. 123-134.

Wright S: 1951.The genetical structure of populations. Annals of Eugenetics 15:323-354.

Yeh FC, Yang RC, Boyle TBJ, Ye ZH and Mao JX: 1997. POPGENE, the user-friendly shareware for population genetic analysis. Molecular Biology and Biotechnology Center, University of Alberta, Edmonton, Alberta, Canada.

Zietkiewicz E, Rafalski A and Labuda D: 1994. Genome fingerprinting by simple sequence repeat (SSR)-anchored polymerase chain reaction amplification. Genomics 20: 176-183. 